\title{
Natural Radioactivity in Selected Soil Samples from the Archaeological of Ur City in Dhi-Qar Province, Iraq
}

\author{
Iman Tarik Al-Alawy ${ }^{1 *}$ and Monar Deya Salim ${ }^{2}$ \\ ${ }^{1}$ AL-Mustansiriyah University, College of Science, Department of physics, Baghdad, Iraq \\ ${ }^{2}$ Dhi -Qar University, College of Science, Department of physics, Dhi -Qar, Iraq \\ *Email: drimantarik@yahoo.com
}

\begin{abstract}
Keywords: Natural Radioactivity; Specific Activity; Nal(TI) Detector; Radium Equivalent Activity; Gamma Absorbed Dose Rate; Annual Effective Dose Rate.
\end{abstract}

\begin{abstract}
The specific activity of natural radionuclides in 24 soil samples collected from antiquities area of Ur city in Dhi-Qar province $(31.0459863 \mathrm{~N}, 46.2534257 \mathrm{E})$ in southern Iraq have been studied and evaluated. Experimental results were obtained by using a Gamma ray spectrometer analysis system consists of a scintillation detector Sodium Iodide activated by Thallium NaI(Tl) of $\left(3^{\prime \prime} \times 3^{\prime \prime}\right)$ crystal dimension at the laboratory of radiation detection and measurement in Science Collage, University of Kufa. The spectrometer has been calibrated for energy by acquiring a spectrum from four standard sources of gamma radiations supplied by spectrum techniques (LLC). The measuring time of all soil samples is 18000 seconds; it was found that, the soil specific activity ranges from $29.93 \pm 2.97$ to $9.99 \pm 2.56 \mathrm{~Bq} / \mathrm{kg}$ for $238 \mathrm{U}$, from $25.66 \pm 2.55$ to $7.77 \pm 2.24 \mathrm{~Bq} / \mathrm{kg}$ for $232 \mathrm{Th}$ and from $397.38 \pm 12.06$ to $215.75 \pm 8.91 \mathrm{~Bq} / \mathrm{kg}$ for $40 \mathrm{~K}$, with mean values of $17.9 \pm 3.02 \mathrm{~Bq} / \mathrm{kg}$, $13.66 \pm 2.41 \mathrm{~Bq} / \mathrm{kg}$ and $314.62 \pm 11.3 \mathrm{~Bq} / \mathrm{kg}$, respectively. The results have been compared with the acceptable data of the worldwide literatures. In order to evaluate the radiological hazard of the natural radioactivity, the radium equivalent activity $\left(\mathrm{Ra}_{\mathrm{eq}}\right)$, the gamma absorbed dose rate (AD), the annual effective dose rate and the both (external and internal) hazard index have been calculated and compared with the acceptable values of the worldwide average (UNSCEAR 2000).
\end{abstract}

\section{INTRODUCTION}

People are exposed to ionizing radiation from the radionuclides that are present in different types of natural sources. Human exposure to ionizing radiation is one of the scientific subjects that attract most public attention [1]. Science natural radiation is responsible for most of the total radiation exposure of the human population, knowledge of the dose received from natural radioactivity, is very important in the discussion of effect on health [2]. Natural Occurring Radionuclides Materials (NORM) is known to be present in rocks and soil [3]. The natural radionuclides of concern are mainly of $238 \mathrm{U}, 232 \mathrm{Th}$ or its progenies and $40 \mathrm{~K}[4,5]$. Natural environmental radioactivity and the associated external exposure due to gamma radiation depend primarily on the geological and geographical conditions, and appear at different levels in the soils of each region in the world $[6,7,8,9]$. The present Sumerian Ur city, which occupied a prominent center in the history of humanity and had a role in stabilizing the concepts of civil result of the interaction between nature and man have been mentioned in the Old Testament where some believe that there is a relationship between Ur city and Abraham (AS). The Ur city, at a distance of $17 \mathrm{Km}$ to the southern west of Nasiriyah city, located at $380 \mathrm{Km}$ to the southern east of Baghdad, and $200 \mathrm{Km}$ to the north of Basrah and the Arabian Gulf. It is located $6 \mathrm{Km}$ to the east of the line of traffic highway between Kuwait-Iraq-Jordan. Because the Ur city settlement since (4000BC). It is believed that the people of this role are the Sumerians first to put the principles of irrigation, developed agriculture and used metals, especially copper. The second round, which passed by Ur city is the role of frozen victory in $(2900 \mathrm{BC})$. This role is called the pre-strains role or the role of the flood, the achievements of this role, the emergence of writing, and the sculpture on the seals. And the role the other, which passed by Ur city is the role of age dawn of dynasties (2800-2400BC) is considered the golden age, reaching Ur city the height of its greatness in all areas in terms of 
architecture, where they found architectural elements such as the bow and trimmings, it appears evident in the Temple (Bear-Lal-Mach) and the Royal Tomb of King Sholeki.

\section{MATERIALS AND METHODS}

In this study, we choose to investigate the level of specific activities of $238 \mathrm{U}, 232 \mathrm{Th}$ and $40 \mathrm{~K}$ in 24 soil samples collected from 8 places in the archaeological city of Ur, as shown in fig. 1 [10]. Soil samples were collected from 8 locations in the antiquities area of Ur city in Dhi-Qar governorate in the south of Iraq. Sampling locations are marked in fig. 1.

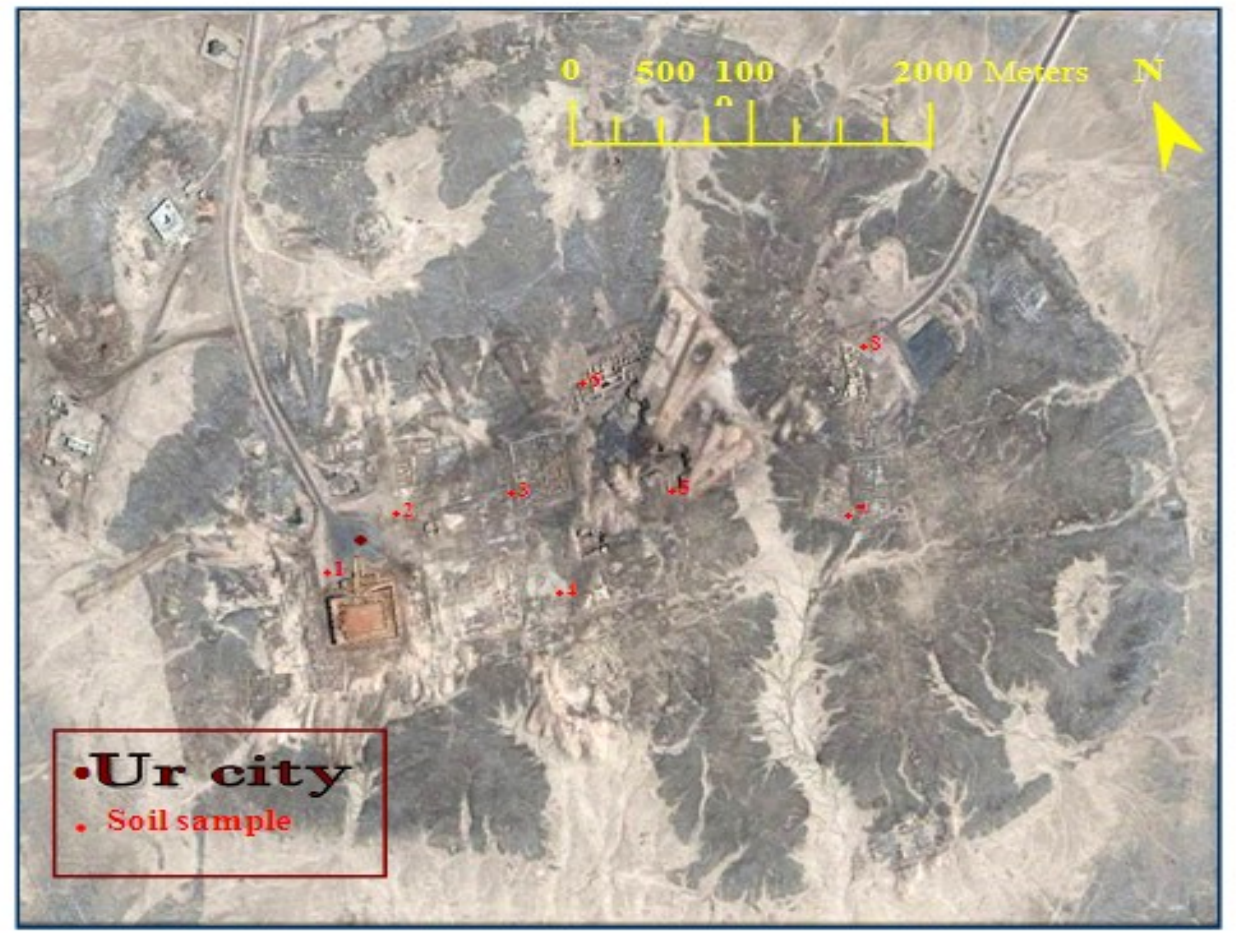

Fig. 1 The sampling locations of 24 soil samples in the antiquities area of Ur city in Dhi-Qar governorate in the southers Iraq [10]/

The samples were ground into a fine powder with a particle size less than $100 \mu \mathrm{m}$ and then dried in a temperature-controlled furnace at $110^{\circ} \mathrm{C}$ for $24 \mathrm{~h}$ to remove moisture. Each sample stored in a sealed polyethylene marinelli beaker for 30days to achieve the secular equilibrium. Marinelli beaker was used as sampling and measuring container. Before use the containers were washed with hydrochloric acid and rinsed with distilled water [11]. The activities of natural radionuclides $238 \mathrm{U}$, $232 \mathrm{Th}$ and $40 \mathrm{~K}$ in the samples was determined by gamma rays spectrometry $\mathrm{NaI}(\mathrm{Tl})$ of $\left(3^{\prime \prime} \times 3 "\right)$ crystal dimensions, supplied by (Alpha Spectra, Inc.-12I12/3), coupled with a multi-channel analyzer (MCA) (ORTEC-Digit Base) with range of 4096 channel joined with analog to digital converter (ADC) unit, through interface. The spectroscopic measurements and analysis are performed via the (MAESTRO-32) software into the PC of the laboratory. The specific activity concentration of $238 \mathrm{U}$ was determined using the gamma-lines $1765 \mathrm{keV}$ of $214 \mathrm{Bi}$. The corresponding results of $232 \mathrm{Th}$ were determined using the gamma-ray lines $2614 \mathrm{keV}$ of $208 \mathrm{Tl}$. The activities of $40 \mathrm{~K}$ were determined from its $1460 \mathrm{keV} \gamma$-line. Counting time interval was 18,000 seconds. The background spectrum was recorded immediately after or before the sample counting. The specific activity concentration of $238 \mathrm{U}$ was determined using the gamma-lines $1765 \mathrm{keV}$ of $214 \mathrm{Bi}$. The corresponding results of $232 \mathrm{Th}$ were determined using the gamma-ray lines $2614 \mathrm{keV}$ of 208Tl. The activities of $40 \mathrm{~K}$ were determined from its $1460 \mathrm{KeV} \gamma$-line. Counting time interval was 18,000 seconds. The background spectrum was recorded immediately after or before the sample counting. The distribution of $238 \mathrm{U}, 232 \mathrm{Th}$ and $40 \mathrm{~K}$ in soil is not uniform. Uniformity with respect to exposure to radiation has been defined in terms of radium equivalent activity $\mathrm{Ra}_{\mathrm{eq}} \mathrm{in} \mathrm{Bq} / \mathrm{kg}$ to compare the specific activity of materials containing different amounts of $238 \mathrm{U}, 232 \mathrm{Th}$ and $40 \mathrm{~K}$. It is calculated using the following relation $[12,13]$ : 


$$
\mathrm{Ra}_{\mathrm{eq}}=\mathrm{AU}+1.43 \mathrm{~A}_{\mathrm{Th}}+0.07 \mathrm{~A}_{\mathrm{K}}
$$

Where $A_{U}, A_{T h}$ and $A_{K}$ are the activity concentrations of $238 \mathrm{U}, 232 \mathrm{Th}$ and $40 \mathrm{~K}$ in $\mathrm{Bq} / \mathrm{kg}$, respectively. While defining $\mathrm{Ra}_{\mathrm{eq}}$ activity according to equation (1), it has been assumed that $370 \mathrm{~Bq} / \mathrm{Kg}$ for $238 \mathrm{U}$ or $259 \mathrm{~Bq} / \mathrm{kg}$ for $232 \mathrm{Th}$ or $4810 \mathrm{~Bq} / \mathrm{kg}$ for $40 \mathrm{~K}$ produce the same gamma dose rate [14]. The external gamma absorbed dose rate in the air at $1 \mathrm{~m}$ above ground level was calculated from the measured activities of $238 \mathrm{U}, 232 \mathrm{Th}$ and $40 \mathrm{~K}$ in soil assuming that other radionuclides, such as $137 \mathrm{Cs}, 113 \mathrm{Cd}$ and $235 \mathrm{U}$ series can be neglected as they contribute very little to the total dose from environmental background $[15,16]$. The calculations were performed according to the following equation [2]:

$\mathrm{D}=0.462 \mathrm{~A}_{\mathrm{U}}+0.604 \mathrm{~A}_{\mathrm{Th}}+0.042 \mathrm{~A}_{\mathrm{K}}$

Where $\mathrm{D}$ is the dose rate in $\mathrm{nGy} / \mathrm{h}$. The external hazard index, $H_{\mathrm{ex}}$, is defined as [12]:

$\mathrm{H}_{\mathrm{ex}}=\mathrm{A}_{\mathrm{U}} / 370+\mathrm{A}_{\mathrm{Th}} / 259+\mathrm{A}_{\mathrm{K}} / 4810$

The value of this index must be less than unity in order to keep the radiation hazard insignificant. The maximum value of $H_{\mathrm{ex}}$ equal to unity corresponds to the upper limit of radium equivalent activity $370 \mathrm{~Bq} / \mathrm{kg}$. To estimate the annual effective dose, the following must be taken into account: (a) The conversion coefficient from absorbed dose in air to effective dose and (b) The indoor occupancy factor. Using the dose rate data obtained from the concentration values of natural radionuclides in soil, adopting the conversion factor of $0.7 \mathrm{~Sv} / \mathrm{Gy}$ [2] from absorbed dose rate in air to effective dose received by adults and considering that people in Hat Yai district, on the average, spent $20 \%$ of their time outdoors, the annual effective doses are calculated [2]:

Outdoor annual effective dose $(\mathrm{Sv})=\mathrm{D} \times 24 \times 365 \times 0.7 \times 0.20$

Indoor annual effective dose $(\mathrm{Sv})=\mathrm{D} \times 24 \times 365 \times 0.7 \times 0.80$

\section{RESULTS AND DISCUSSION}

Fig. 2 shows the distribution of specific activity concentrations of $40 \mathrm{~K}, 238 \mathrm{U}$ and $232 \mathrm{Th}$ radionuclides for 24 samples of soils collected from 8 different locations in Ur city region, taken from three different depths $0-5,5-10$ and $10-15 \mathrm{~cm}$. For $40 \mathrm{~K}$, the values have been found to vary between $215.75 \pm 8.91 \mathrm{~Bq} / \mathrm{kg}$ in sample A3 and $397.38 \pm 12.02 \mathrm{~Bq} / \mathrm{kg}$ in sample A1 at depth $5-10 \mathrm{~cm}$ with an average value $314.62 \pm 11.3 \mathrm{~Bq} / \mathrm{kg}$. For $238 \mathrm{U}$ vary from $9.99 \pm 2.56 \mathrm{~Bq} / \mathrm{kg}$ in sample A3 to $29.93 \pm 2.98 \mathrm{~Bq} / \mathrm{kg}$ in sample A7 at depth $5-10 \mathrm{~cm}$ with an average of $17.9 \pm 3.02 \mathrm{~Bq} / \mathrm{kg}$. While for $232 \mathrm{Th}$ it varies from $7.77 \pm 2.24 \mathrm{~Bq} / \mathrm{kg}$ in sample A6 at depth $10-15 \mathrm{~cm}$ to $25.66 \pm 2.55 \mathrm{~Bq} / \mathrm{kg}$ in sample A1 at depth $5-10 \mathrm{~cm}$ with an average of $13.66 \pm 2.41 \mathrm{~Bq} / \mathrm{kg}$. Hence, at depth $0-5 \mathrm{~cm}$, the minimum values for $40 \mathrm{~K}, 238 \mathrm{U}$ and $232 \mathrm{Th}$ radionuclides are $245.57 \pm 9.35 \mathrm{~Bq} / \mathrm{kg}$ in sample A6, $14.2 \pm 3.07 \mathrm{~Bq} / \mathrm{kg}$ in sample $\mathrm{A} 7$ and $10.74 \pm 2.84 \mathrm{~Bq} / \mathrm{kg}$ in sample A7 respectively, while the maximum values are $393.35 \pm 12.1 \mathrm{~Bq} / \mathrm{kg}$ recorded in sample $\mathrm{A} 3,21.97 \pm 2.96 \mathrm{~Bq} / \mathrm{kg}$ in sample A8 and $24.26 \pm 2.87 \mathrm{~Bq} / \mathrm{kg}$ in sample $\mathrm{A} 1$, with an average of $318.2 \pm 11.05 \mathrm{~Bq} / \mathrm{kg}, 17.33 \pm 3.04 \mathrm{~Bq} / \mathrm{kg}$ and $13.83 \pm 2.33 \mathrm{~Bq} / \mathrm{kg}$ respectively. For depth $5-10 \mathrm{~cm}$, the minimum value for $40 \mathrm{~K}, 238 \mathrm{U}$ and $232 \mathrm{Th}$ radionuclides is $257.29 \pm 10.67 \mathrm{~Bq} / \mathrm{kg}$ in sample $\mathrm{A} 3,9.99 \pm 2.56 \mathrm{~Bq} / \mathrm{kg}$ in sample $\mathrm{A} 3$ and $8.33 \pm 1.65 \mathrm{~Bq} / \mathrm{kg}$ in sample $\mathrm{A} 3$ respectively, while the maximum value is $397.38 \pm 12.02 \mathrm{~Bq} / \mathrm{kg}$ in sample A1, $29.93 \pm 2.98 \mathrm{~Bq} / \mathrm{kg}$ in sample $\mathrm{A} 7$ and $25.66 \pm 2.55 \mathrm{~Bq} / \mathrm{kg}$ sample $\mathrm{A} 1$, with an average values $326.71 \pm 11.16 \mathrm{~Bq} / \mathrm{kg}, 19.66 \pm 2.94 \mathrm{~Bq} / \mathrm{kg}$ and $15.54 \pm 2.44 \mathrm{~Bq} / \mathrm{kg}$ respectively. For depth 10 $15 \mathrm{~cm}$, the minimum value for $40 \mathrm{~K}, 238 \mathrm{U}$ and $232 \mathrm{Th}$ radionuclides is $215.75 \pm 8.91 \mathrm{~Bq} / \mathrm{kg}$ in sample $\mathrm{A} 3,11.79 \pm 2.82 \mathrm{~Bq} / \mathrm{kg}$ in sample $\mathrm{A} 3$ and $7.77 \pm 2.24 \mathrm{~Bq} / \mathrm{kg}$ recorded in sample A6 respectively, while the maximum value is $394.62 \pm 11.24 \mathrm{~Bq} / \mathrm{kg}$ in sample $\mathrm{A} 5,23.73 \pm 2.89 \mathrm{~Bq} / \mathrm{kg}$ recorded in sample A7 and $15.38 \pm 2.48 \mathrm{~Bq} / \mathrm{kg}$ recorded in sample $\mathrm{A} 7$, with an average values $298.95 \pm 10.8 \mathrm{~Bq} / \mathrm{kg}$, $16.71 \pm 3.09 \mathrm{~Bq} / \mathrm{kg}$ and $11.7 \pm 2.45 \mathrm{~Bq} / \mathrm{kg}$ respectively. Generally, the specific activity concentration values in all soil samples of Ur city region are less than the worldwide average $35 \mathrm{~Bq} / \mathrm{kg}$ for $238 \mathrm{U}$, $30 \mathrm{~Bq} / \mathrm{kg}$ for $232 \mathrm{Th}$ and $400 \mathrm{~Bq} / \mathrm{kg}$ for $40 \mathrm{~K}[2]$.

Fig. 3 shows the Radium equivalent $\mathrm{Ra}_{\mathrm{eq}}$ activities for the soil samples versus soil depth of the archeological UR city. $\mathrm{Ra}_{\mathrm{eq}}$ values vary from $41.72 \pm 5.74 \mathrm{~Bq} / \mathrm{kg}$ in sample A8 to $92.29 \pm 7.47 \mathrm{~Bq} / \mathrm{kg}$ in sample A8 with an average value of $61.67 \pm 7.03 \mathrm{~Bq} / \mathrm{kg}$. For depth $0-5 \mathrm{~cm}$, the 
minimum value is $52.25 \pm 6.07 \mathrm{~Bq} / \mathrm{kg}$ recorded in sample $\mathrm{A} 2$ while the maximum value is $81.56 \pm 9.17 \mathrm{~Bq} / \mathrm{kg}$ in sample A1 with an average of $61.62 \pm 7.23 \mathrm{~Bq} / \mathrm{kg}$. For depth $5-10 \mathrm{~cm}$, the minimum value is $41.72 \pm 5.74 \mathrm{~Bq} / \mathrm{kg}$ recorded in sample $\mathrm{A} 3$ while the maximum value is $92.29 \pm 7.47 \mathrm{~Bq} / \mathrm{kg}$ in sample $\mathrm{A} 1$ with an average of $66.93 \pm 7.3 \mathrm{~Bq} / \mathrm{kg}$. For depth $0-15 \mathrm{~cm}$, the minimum value is $42.37 \pm 6.65 \mathrm{~Bq} / \mathrm{kg}$ recorded in sample $\mathrm{A} 3$ while the maximum value is $64.63 \pm 7.57 \mathrm{~Bq} / \mathrm{kg}$ in sample A1 with an average of $56.21 \pm 7.4 \mathrm{~Bq} / \mathrm{kg}$. It can be seen that the $\mathrm{Ra}_{\mathrm{eq}}$ values for all soil samples are lower than the recommended permissible value $370 \mathrm{~Bq} / \mathrm{kg}$ [2]. The activity levels due to terrestrial background radiation are related to the type of rock from which the soil originates. No correlation is found between activity and depth. The measured values of radioactivity show that it is randomly distributed in different depths of the soil.

Fig. 4 shows the distribution of absorbed dose rate (AD) for the soil samples versus soil depth of the archeological Ur city. The calculated results of the absorbed dose rate shows that the highest value is $43.78 \mathrm{nGy} / \mathrm{h}$ noted in sample A1 at depth $5-10 \mathrm{~cm}$, whereas the lowest value is $20.34 \mathrm{nGy} / \mathrm{h}$ noted in sample A3 at depth $5-10 \mathrm{~cm}$. The average value is $29.66 \mathrm{nGy} / \mathrm{h}$. The measurements indicate that the absorbed dose rate values due to the depth of soil $0-5 \mathrm{~cm}$ have a minimum value $25.24 \mathrm{nGy} / \mathrm{h}$ in sample $\mathrm{A} 2$ and a maximum value $38.72 \mathrm{nGy} / \mathrm{h}$ recorded in sample A1 with an average $29.77 \mathrm{nGy} / \mathrm{h}$. For depth $5-10 \mathrm{~cm}$, the minimum value is $20.34 \mathrm{nGy} / \mathrm{h}$ recorded in sample A3 and the maximum value is $43.78 \mathrm{nGy} / \mathrm{h}$ in sample A1 with an average of $32.08 \mathrm{nGy} / \mathrm{h}$. While for depth $10-15 \mathrm{~cm}$, the minimum value is $20.36 \mathrm{nGy} / \mathrm{h}$ in sample A3 and the maximum value is $31.38 \mathrm{nGy} / \mathrm{h}$ recorded in sample A1 with an average of $27.24 \mathrm{nGy} / \mathrm{h}$. The values of absorbed dose rate for soil sample are below the worldwide average limit $55 \mathrm{nGy} / \mathrm{h}[17]$.

Fig. 5 shows indoor and outdoor annual effective doses for the soil samples versus soil depth of the archeological Ur city, respectively. The calculated values of annual effective doses shows that the maximum values of indoor and outdoor are $0.215 \mathrm{mSv} / \mathrm{y}$ and $0.054 \mathrm{mSv} / \mathrm{y}$ recorded in sample A1 at depth $5-10 \mathrm{~cm}$ and the minimum values were 0.099 and $0.025 \mathrm{mSv} / \mathrm{y}$ recorded in sample A3 at depth $5-10 \mathrm{~cm}$. The average values of annual indoor and outdoor effective dose are 0.145 and $0.036 \mathrm{mSv} / \mathrm{y}$ respectively. For depth $0-5 \mathrm{~cm}$ the minimum values of (indoor and outdoor) are 0.124 and 0.031 recorded in sample A2 while the maximum values are 0.19 and 0.047 recorded in sample A1 with an average values 0.145 and 0.036 respectively. For depth $5-10 \mathrm{~cm}$, the minimum values are 0.099 and 0.025 recorded in sample A3 while the maximum values are 0.215 and 0.054 recorded in sample A1 with an average values 0.157 and 0.039 respectively. For depth $10-15 \mathrm{~cm}$, the minimum values are 0.1 and 0.025 recorded in sample A3, while the maximum values are 0.154 and 0.038 recorded in sample A1 with an average values 0.133 and 0.033 respectively. All values of indoor and outdoor annual effective dose are less than worldwide average $1 \mathrm{mSv} / \mathrm{y}$ which is recommended by International Commission on Radiological Protection (ICRP 1993) [17].

The elemental concentrations of $238 \mathrm{U}$ varies between $0.808 \mathrm{ppm}$ in soil sample A3 and $2.423 \mathrm{ppm}$ in soil sample A7 at depth $5-10 \mathrm{~cm}$, with an average value $1.449 \mathrm{ppm}$, whereas that of $232 \mathrm{Th}$ varies between $1.914 \mathrm{ppm}$ recorded in soil sample A6 at depth $10-15 \mathrm{~cm}$ and $6.321 \mathrm{ppm}$ recorded in soil sample A1 at depth $5-10 \mathrm{~cm}$, with an average value $3.366 \mathrm{ppm}$. For $40 \mathrm{~K}$ radionuclide, the elemental concentrations ranged from $0.689 \%$ recorded in sample A3 to $1.26 \%$ recorded in sample A5 at depth $10-15 \mathrm{~cm}$, with an average value $1.005 \%$. For depth $0-5 \mathrm{~cm}$, the minimum values of the elemental concentrations of $40 \mathrm{~K}, 238 \mathrm{U}$, and $232 \mathrm{Th}$ radionuclides are $0.784 \%$ recorded in sample A6, $1.15 \mathrm{ppm}$ recorded in sample A7 and $2.645 \mathrm{ppm}$ recorded in sample A7 respectively, while the maximum values are $1.256 \%$ recorded in sample A3, 1.778ppm recorded in sample A8 and 5.975ppm recorded in sample A1 respectively, with an average of $1.016 \%$, $1.403 \mathrm{ppm}$ and $3.408 \mathrm{ppm}$ respectively. While for depth $5-10 \mathrm{~cm}$, the minimum values of are $0.822 \%$ recorded in sample A3, 0.808ppm recorded in sample A3 and 2.052ppm recorded in sample A3 respectively, while the maximum values are $1.126 \%$ recorded in sample A1, 2.423ppm recorded in sample A7 and $6.321 \mathrm{ppm}$ recorded in sample A1 respectively, with an average of $1.025 \%$, 
$1.591 \mathrm{ppm}$ and $3.807 \mathrm{ppm}$ respectively. Also for the depth $10-15 \mathrm{~cm}$, the minimum values of $40 \mathrm{~K}$, $238 \mathrm{U}$, and $232 \mathrm{Th}$ radionuclides are $0.689 \%$ recorded in sample A3, $0.954 \mathrm{ppm}$ recorded in sample A3 and 1.914ppm recorded in sample A6 respectively, while the maximum values are $1.26 \%$ recorded in sample A5, 1.921ppm recorded in sample A7 and 3.788ppm recorded in sample A7 respectively, with an average of $0.954 \%, 1.352 \mathrm{ppm}$ and $2.881 \mathrm{ppm}$ respectively. The Maximum value $5.975 \mathrm{ppm}$ of $232 \mathrm{Th}$ elemental concentrations was recorded in soil sample A1 at depth $0-5 \mathrm{~cm}$, while maximum value $6.321 \mathrm{ppm}$ of $232 \mathrm{Th}$ was recorded in soil sample A1 at the depth $5-10 \mathrm{~cm}$ and the maximum value $3.788 \mathrm{ppm}$ of $232 \mathrm{Th}$ was found in soil sample A7 at depth $10-15 \mathrm{~cm}$. These values are less than the worldwide averagev7.38ppm for $232 \mathrm{Th}$. All results of elemental concentrations are within the permissible limits $1.28 \%$ for $49 \mathrm{~K}, 2.83 \mathrm{ppm}$ for $238 \mathrm{U}$, and $7.38 \mathrm{ppm}$ for $232 \mathrm{Th}$ [2].

Fig. 6 shows the distribution of external and internal hazard index for the soil samples with the soil depth of the archeological Ur city. The maximum values of external and internal hazard index are 0.249 and 0.316 recorded in sample A1 at depth $5-10 \mathrm{~cm}$ and the minimum values of external and internal hazard index are 0.112 and 0.139 noted in sample A3 at depth $5-10 \mathrm{~cm}$, the average values of external and internal hazard index are 0.166 and 0.215 respectively. Therefore, for the depth $0-5 \mathrm{~cm}$, the minimum values of external and internal are 0.141 and 0.18 recorded in sample A2 while the maximum values are 0.22 and 0.27 recorded in sample A1 with an average of 0.166 and 0.212 respectively. Also, for depth $5-10 \mathrm{~cm}$, the minimum values are 0.112 and 0.139 recorded in sample A3 while the maximum values are 0.249 recorded in sample A1 and 0.318 recorded in sample A7 with an average of 0.18 and 0.233 respectively. While, for $10-15 \mathrm{~cm}$ depth, the minimum values are 0.114 and 0.146 recorded in sample A3 while the maximum values are 0.147 recorded in sample A1 and 0.233 recorded in sample A7 with an average of 0.152 and 0.197 respectively. All soil samples of Ur city are not exceed the upper limit for $\left(\mathrm{H}_{\mathrm{ex}}\right.$ and $\left.\mathrm{H}_{\mathrm{in}}\right)$, which is unity [2].

Finally, fig. 7 shows a set of gamma-ray spectra of a typical samples from the soil under study for Ur city, which analyzed by $\mathrm{NaI}(\mathrm{Tl})$ detector.

All the results demonstrated by this study make the archaeological of Ur city in a safe environment from exposure of radiation, and there is no risk to workers or tourists coming to see the archaeological ruins. Despite the presence of the military base and airport of Imam Ali (AS) military, near the archeological city of Ur (about $1.8 \mathrm{~km}$ ). The activity levels due to terrestrial background radiation are related to the type of rock from which the soil originates. As regard of activity with respect to depth, no correlation was found between activity and depth. The measured values of radioactivity show that it's randomly distributed in different depth of the soil.

\section{CONCLUSIONS}

The environmental monitoring of natural background radiation using Sodium Iodide $\mathrm{NaI}(\mathrm{Tl})$ detector revealed is a good technique for measuring the distribution of the natural radiation levels in soil and pottery samples. From the obtained result, one could see that the distribution was not uniform. The measured values of radioactivity show that it is randomly distributed in different depth of the soil. Also artificial radionuclide was not detected in any of the measured samples. The obtained results confirm some conclusions as below:

1- The present work has shown that the radioactivity concentration of $238 \mathrm{U}, 232 \mathrm{Th}$ and $40 \mathrm{~K}$ are generally acceptable and have consistent values with those reported by many other countries in the world for samples.

2- Since the radiation levels were within permissible limits, thus the radioactive hazard is low for human beings (employees and tourists) in these areas.

3- Specific activity of $40 \mathrm{~K}$ is much higher than that of $238 \mathrm{U}$ and $232 \mathrm{Th}$. 
4- The gamma absorbed dose rate of samples varies appreciably from one sample to another due to the variation of $238 \mathrm{U}, 232 \mathrm{Th}$ and $40 \mathrm{~K}$ contents.

5- The estimated average absorbed dose rates in air for the studied area are below or comparable with world average $(55 \mathrm{nGy} / \mathrm{h})$. All average values of annual indoor and outdoor effective dose were less than the permissible limit.

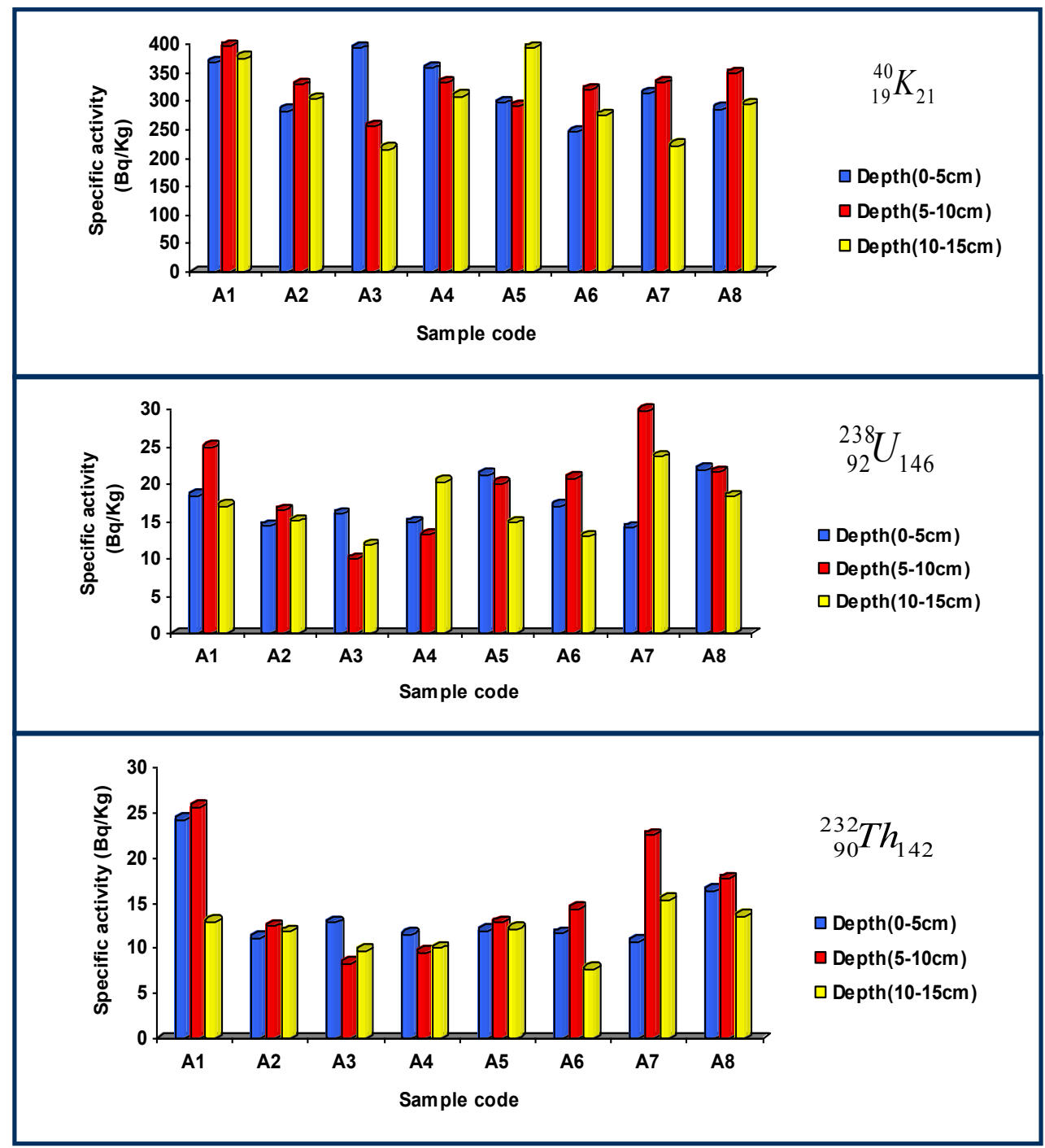

Fig. 2 Variation of specific activity concentration of 238U, 232Th and 40K versus soil depth for Ur city region.

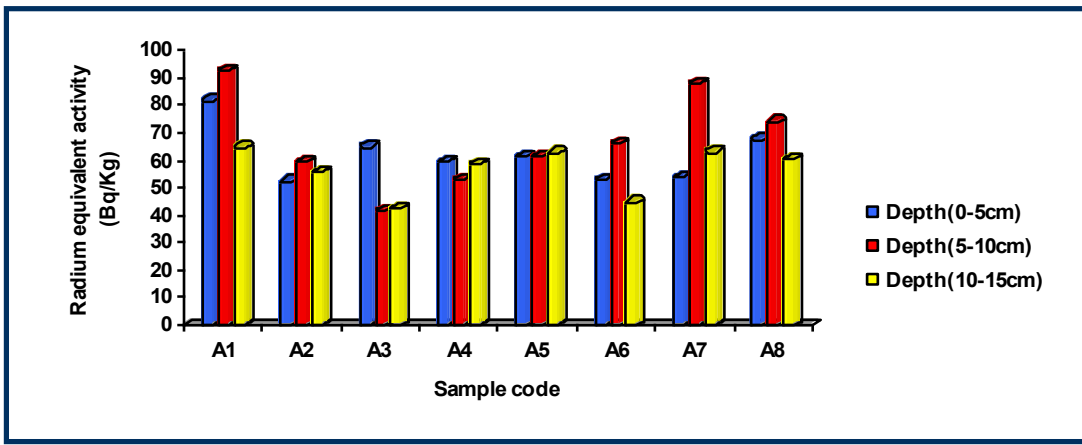

Fig. 3 Variation of Radium equivalent activity versus soil depth for Ur city region. 


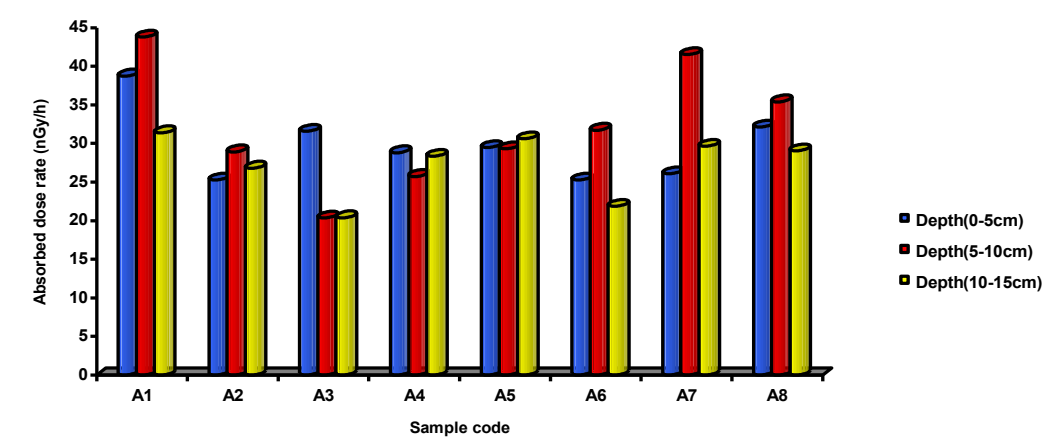

Fig. 4 Variation of absorbed dose rate versus soil depth for Ur city region.

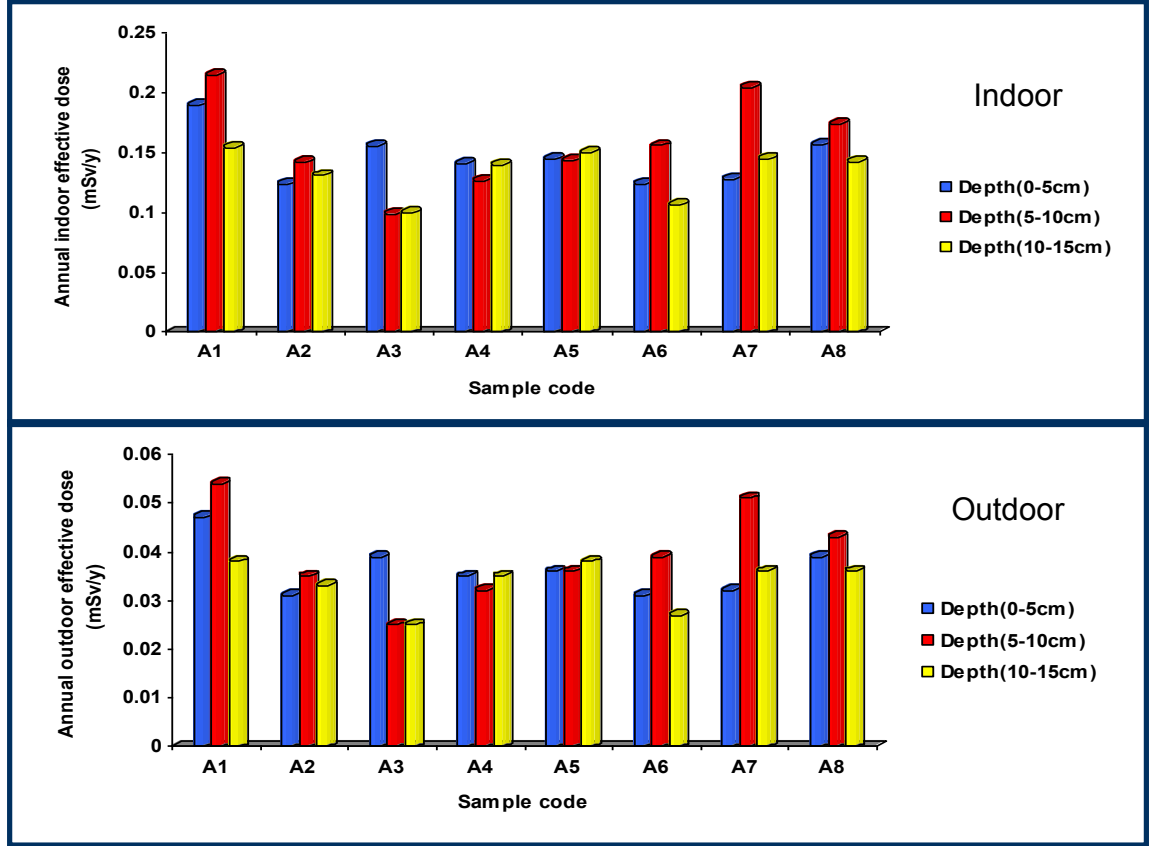

Fig. 5 Variation of annual effective doses (indoor and outdoor) versus soil depth for Ur city region.

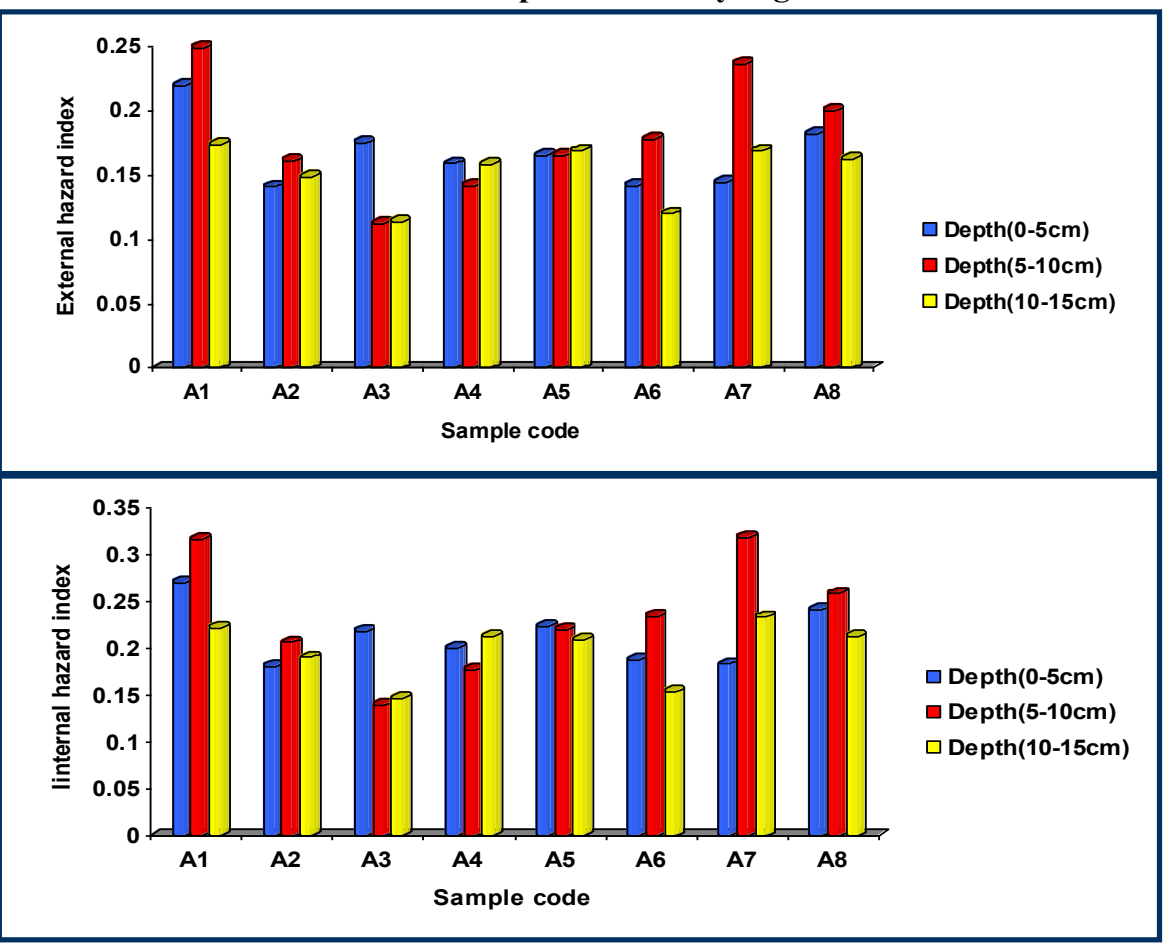

Fig. 6 Variation of (external and internal) hazard index versus soil depth for Ur city region 


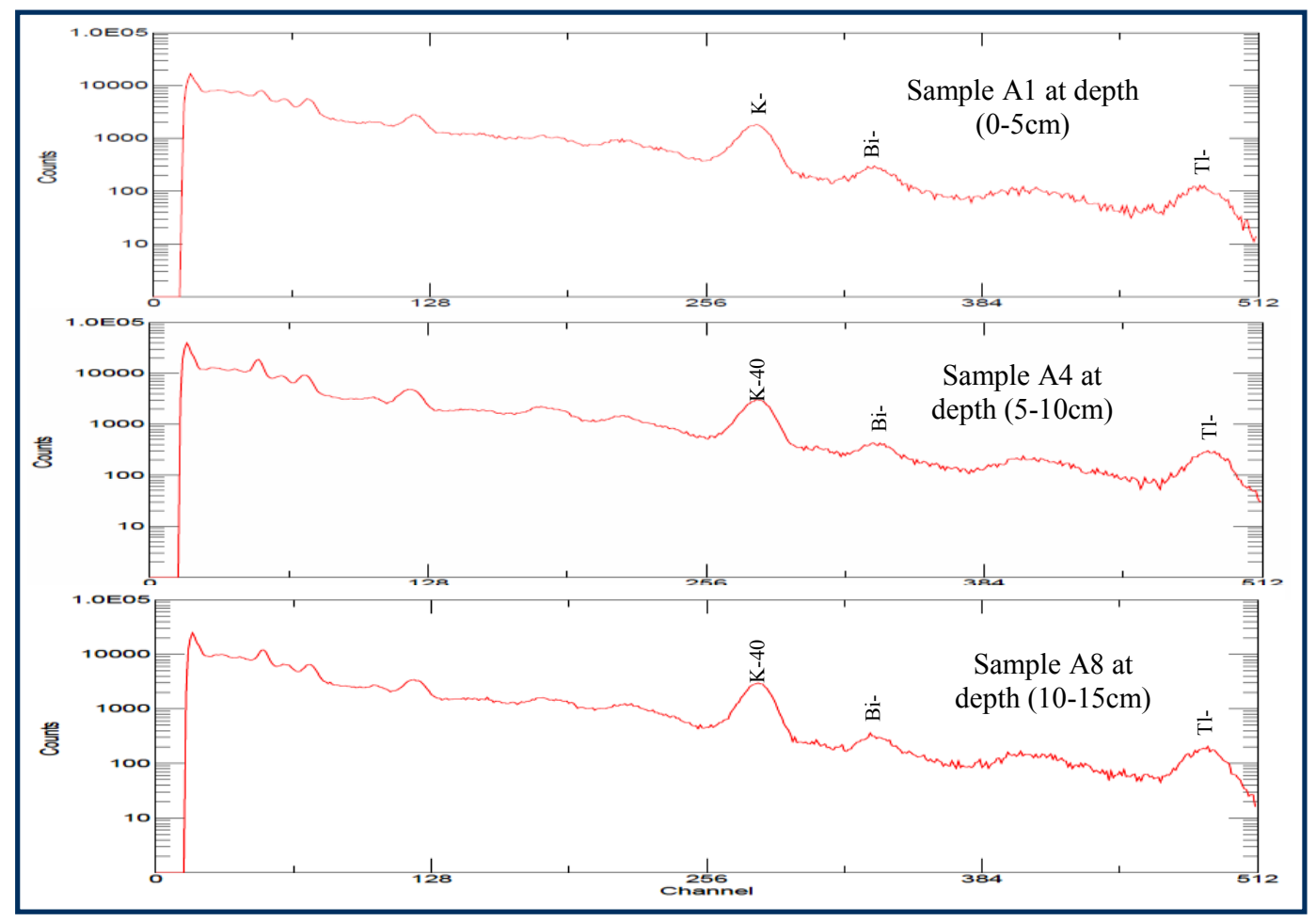

Fig. 7 Gamma-ray spectrum of three typical soil samples from Ur city region.

\section{Acknowledgement}

Authors thankful are to the Department of Physics, Kufa University for providing facilities for instrumental support. Also, the greater thankful is for the Organization of Antiquities and Environment in Dhi-Qar Province, Iraq.

\section{References}

[1] O.B. Flores, A. M. Estrada, R. R. Suarez, J. T. Zerquera and A. H. Pe'rez, "Natural radionuclide content in building materials and gamma dose rate in dwellings in Cuba", Environmental Radioactivity, 99 (2008) 1834-1837.

[2] UNSCEIR, United Nations Scientific Committee on the Effects of Ionizing Radiation, "Sources and Effects of Ionizing Radiation". The UNSCEIR Report to the General Assembly. UN, New York, USA. (2000) 111-125.

[3] M. Yasir, A. Ab-Majid and R. Yahaya,"Study of natural radionuclides and its radiation hazard index in Malaysian building materials", Radioanalytical and Nuclear Chemistry, 273(3) (2007) 539-541.

[4] D.M. Hamby and A.K. Tynybekov, "Uranium, thorium, and potassium in soils along the shore of Lake Issyk-Kyol in the Kyrghyz Republic", Environmental Monitoring and Assessment, 73 (2) (2002) 101-108.

[5] D. M. Hamby and A. K. Tynybekov, "A screening assessment of external radiation levels on the shore of Lake Issyk-Kyol in the Kyrghyz Republic", Health Physics, 77(4) (1999) 427-430.

[6] M.J. Anagnostakis, E.P. Hinis, S.E. Simopoulos and M.G. Angelopoulos, "Natural radioactivity mapping of Greek surface soils", Environmental International. 22 (1996) 3-8.

[7] N. Petropoulos, M. J. Anagnostakis, E. P. Hinis and S. E. Simopoulos, "Geographical mapping and associated fractal analysis of the long-lived Chernobyl fallout radionuclides in Greece", Environmental Radioactivity, 53 (2001) 59-66.

[8] M. J. Anagnostakis, E.P. Hinis, and S.E. Simopoulos, "238U and its daughter products in Greek surface soils, Radioactivity in the Environment", Environmental Radioactivity, 7 (2005) 10251029. 
[9] M. A. J. Shender,"Measurement of natural radioactivity levels in soil in Tripoli”, Applied Radiation and Isotopes. 48(1) (1997) 147-148.

[10] A.M. Al-Hamdani and E.C. Stone, "satellite image: The satellite images are from Blue sat company and date to 2003-2008", Laboratory of Geographic information system at the State University of New York at Stony Brook.

[11] G. F. Knoll, "Radiation detection and measurement", John Wiley and Sons Inc., NewYork, USA. (2000) 29-31.

[12] J. Beretka and P.J. Mathew, "Natural radioactivity of Australian building materials, industrial wastes and by-products. Journal of Health Physics", Health Physics, 48 (1985) 87-95.

[13] KN. Yu. Peter, Z.J. Guan, M.J. Stokes and E.C.M. Young, "The assessment of the natural radiation dose committed to the Hong Kong people", Environmental Radioactivity, 17(1) (1992) 31-48.

[14] D.C. Kocher and A.L. Sjoreen, "Dose rate conversion factors for external exposure to photo emitters in soil", Health Physics. 48(1) (1985) 193-205.

[15] P. Jacob, H.G. Paretzke, H. Rosenbaum and M.J. Zankl, " Radiation Protection Dosimetry. 14(4) (1986) 299-310.Matching in the Accidental urban contamination: proceedings of a workshop held at Roskilde, Denmark, June 9-12, (1987).

[16] N. Sharma, R. Sharma and H.S. Virk, "Environmental radioactivity: A case study of Punjab, India", Advances in Applied Science Research, 2(3) (2011) 186-190. Quartz rock, Tectonophysics, 65 (No.3-4) (2011) 281-290.

[17] ICRP, International Commission on Radiological Protection, "Protection against radon-222 at home and at work", ICRP Publications 65 (Oxford: Pergamon Press). Ann.ICRP 23(2) (1993) 81. 